\title{
Assessment of Serum Electrolyte Levels \& HbA1C Levels among Type 2 Diabetic Sudanese Patients with Macrovascular Complications in Khartoum State
}

\author{
Ragda Hafaz Ramadan, Abdulmwla Muhammed Abdullah* \\ Department of Clinical Chemistry, Faculty of Medical Laboratory Sciences, Al-Neelain University, Khartoum, Sudan \\ Email: ^mula200099@yahoo.co.uk
}

How to cite this paper: Ramadan, R.H. and Abdullah, A.M. (2020) Assessment of Serum Electrolyte Levels \& HbA1C Levels among Type 2 Diabetic Sudanese Patients with Macrovascular Complications in Khartoum State. Open Access Library Journal, 7: e6110. https://doi.org/10.4236/oalib.1106110

Received: January 28, 2020

Accepted: March 14, 2020

Published: March 17, 2020

Copyright $\odot 2020$ by author(s) and Open Access Library Inc.

This work is licensed under the Creative Commons Attribution International License (CC BY 4.0).

http://creativecommons.org/licenses/by/4.0/

(c) (i) Open Access

\begin{abstract}
Background: Recently epidemiological studies have shown that type 2 diabetes mellitus is great a risk factor for cardiovascular mortality. Electrolyte abnormalities are commonly encountered in chronic diabetes mellitus type 2 patients. Aim: The aim of this study was to estimate serum electrolyte levels \& HbA1C levels among Sudanese diabetic Patients with macrovascular complications in Khartoum State, Sudan. Materials \& Methods: In this case, control hospital based study conducted in Khartoum state. Hundred subjects were involved; fifty were type 2 diabetes patients and fifty healthy subjects control group sex and age matched. Serum $\mathrm{Na}$ and $\mathrm{K}$ levels were estimated by Automated Biochemistry Analyzer (Easylyte electrolyte) and $\mathrm{HbA1C}$ by Automated Biochemistry Analyzer (Mindary Bs380). Result: The mean serum level of sodium and potassium in type 2 diabetes patients was significantly decreased $(137.7 \pm 4.05$ vs $139.8 \pm 3.62 \mathrm{mmol} / \mathrm{l}, \mathrm{p}=0.008$ and $3.60 \pm 0.20$ vs $3.92 \pm 0.22 \mathrm{mmol} / \mathrm{l}, \mathrm{p}=0.03$ respectively). Whereas, HA1C level showed significant increases in the test group when compared with reference group $(9.68 \pm 1.24$ vs $5.44 \% \pm 0.42 \%, p=0.000)$. Across gender, our study observed no significant alteration in serum $\mathrm{Na}$ and $\mathrm{K}$ levels $(\mathrm{p}>0.05)$ in type 2 diabetic patients. Furthermore, serum $\mathrm{Na}^{+}$level was significantly correlated with $\mathrm{K}^{+}$ $(\mathrm{R}=0.369, \mathrm{p}=0.008)$. Whereas, both $\mathrm{Na}^{+}$and $\mathrm{K}^{+}$were in significantly correlated with patients age, $\mathrm{HbAlc}(\%)$, and duration of DM ( $\mathrm{p}>0.05)$. In contrast, HA1C is significantly correlated with the duration of diabetes $(\mathrm{R}=$ $0.425, p=0.002)$. Conclusion: Our study revealed significant alterations in electrolyte levels in type 2 diabetes mellitus and proper hyperglycemic control with evaluation of electrolyte levels can reduce the complication accompanied with electrolyte disbalance in type $2 \mathrm{DM}$.
\end{abstract}




\section{Subject Areas}

Biochemistry, Diabetes \& Endocrinology

\section{Keywords}

Electrolyte, HbA1C, Sodium, Potassium, Macro Vascular Complications, Sudanese

\section{Introduction}

Diabetes is a major worldwide health problem. Diabetes mellitus is an endocrine disorder affecting millions of people every year. Diabetes remains latent and its secondary complications lead to the mortality and morbidity [1]. Type 2 diabetes mellitus is a common chronic disease of adults, which presents with acute, sometimes life-threatening, symptomatic hyperglycemia [2]. Serious long-term complications associated to type 2 diabetes include cardiovascular disease, stroke, chronic kidney disease, foot ulcers, and damage to the eyes. Recently, epidemiological studies have shown that type 2 diabetes mellitus is a great risk factor for macrovascular mortality [2] [3].

There is a strong relation between electrolytes and T2DM. Electrolytes play an important role in maintaining acid-base balance, blood clotting, control body fluid and muscle contractions. The electrolytes in serum include sodium $\left(\mathrm{Na}^{+}\right)$, potassium $\left(\mathrm{K}^{+}\right)$, calcium $\left(\mathrm{Ca}^{2+}\right)$ and magnesium $\left(\mathrm{Mg}^{2+}\right)$ [4]. These electrolytes play an important role in intermediary metabolism and cellular function, including enzyme activities and electrical gradients. Serum concentrations of electrolytes have been shown to change with plasma glucose levels [5]. Disturbed electrolyte distribution may affect the course of diabetes and its management. The relation between blood glucose and electrolytes is complex and is related to a number of other factors, like age and associated conditions [6]. Glucose is an osmotically active substance and hyperglycemia increases serum osmolality and results in movement of water out of the cells and reduction of sodium levels by the dilutional effect [6] [7]. The osmotic effect of glucose also causes osmotic diuresis causing a decrease in circulating blood volume and cellular dehydration due to the shift of water from intracellular spaces causing cellular dehydration [8].

Glycosylated hemoglobin (HbA1c) is the most vital target of glycemic control. The desirable value for $\mathrm{HbAlc}$ is values below $6.0 \%$. HbAlc is important standard in analysis of patients' status that indicates the average blood glucose during the past three months which is essential to ensure the optimal care of diabetic patients [9] [10]. The research has revealed that with each one percent reduction in the value of HbA1c, the risk of micro vascular complications is reduced by 40 percent. This study carried to measured serum electrolyte levels and $\mathrm{HbA1C}$ and examined their relationship with macrovascular complications in 
Sudanese adults with type 2 diabetes [11].

\section{Materials \& Methods}

Study design and population: This is case-control study was performed at Asia hospital-Khartoum state during May to December 2019, including hundred subjects, fifty patients known diagnosed with Diabetes Mellitus Type 2 (26 (52\%) females and 24 (48\%) males), with mean age $55.5 \pm 8.11$ year and duration of diabetes $2.00-23.0$ years, and other fifty healthy individuals as control groups sex and age matched.

Inclusion criteria: Sudanese patients diagnosed with type 2 diabetes mellitus with age more than 40 years and less than 70 years.

Exclusion criteria: Patients who had type 1 diabetes mellitus, known malignancy infectious disease and any type 2 diabetic patients refuse to participate in this study were excluded.

Data collection and clinical examination: Each site used a standardized questionnaire which collected the demographic and symptom information assessed in this study.

Sample collection: Blood was taken from each participant by standard procedures. Plasma sodium $\left(\mathrm{Na}^{+}\right)$and potassium $\left(\mathrm{K}^{+}\right)$, were estimated by ion selective electrode method in fully Automated Biochemistry Analyzer (Easylyte electrolyte). HbA1C was estimated by enzymatic method in fully Automated Biochemistry Analyzer (Mindary Bs380).

Ethical consideration: ethical approval was taken from Elneelain university research council and written consent was obtained from all participants in this study.

Quality control: Samples representing the normal and pathological levels of sodium, potassium and HA1C were used for assessment of the quality control. Results \pm 2 SD of the target values of the control sera were accepted.

Statistical analysis: Data was analyzed by computer software by using SPSS program manual master sheet (SPSS version 21), the results were expressed as frequency percentage, mean and $\mathrm{SD}$, and the independent $\mathrm{t}$-test was used to compare the mean levels of sodium, potassium and HA1C in case and control. Correlation between measured variable was significant at $\mathrm{p} \leq 0.05$.

\section{Results}

A total of 100 subjects were included for the study. All subjects categorized in two groups, 50 patients with type 2 diabetes mellitus case (26 (52\%) females and 24 (48\%) males). With mean age $55.5 \pm 8.11$ years and duration of diabetes 2.00 23.0 years. In addition to other 50 healthy subjects age and sex matched control group in Table 1.

As presented in Table 2 the mean serum level of both sodium and potassium in type 2 diabetes patients were significantly decreased when compared to the control group $(137.7 \pm 4.05$ vs $139.8 \pm 3.62 \mathrm{mmol} / \mathrm{l}, \mathrm{p}=0.008$ and $3.60 \pm 0.20$ vs 
Table 1. Mean age and duration of diabetes mellitus in the study group.

\begin{tabular}{cccc}
\hline Variables & Minimum & Maximum & Mean \pm SD \\
\hline Age (year) & 40.0 & 70.0 & $55.5 \pm 8.11$ \\
Duration (year) & 2.00 & 23.0 & $9.44 \pm 3.97$ \\
\hline
\end{tabular}

Table 2. Mean comparison of study parameters in case versus control group.

\begin{tabular}{cccc}
\hline Parameters & Case $($ Mean $\pm \mathrm{SD})$ & Control $($ Mean $\pm \mathrm{SD})$ & $P$-value \\
\hline $\mathrm{Na}^{+}(\mathrm{mmol} / \mathrm{L})$ & $137.7 \pm 4.05$ & $139.8 \pm 3.62$ & 0.008 \\
$\mathrm{~K}^{+}(\mathrm{mmol} / \mathrm{L})$ & $3.60 \pm 0.20$ & $3.92 \pm 0.22$ & 0.03 \\
$\mathrm{HbA1c}(\%)$ & $9.68 \pm 1.24$ & $5.44 \pm 0.42$ & 0.000 \\
$\mathrm{SPB}(\mathrm{mmHg})$ & $133.0 \pm 3.73$ & $120.6 \pm 0.86$ & 0.000 \\
$\mathrm{DBP}(\mathrm{mmHg})$ & $88.70 \pm 2.38$ & $80.52 \pm 1.63$ & 0.000 \\
\hline
\end{tabular}

$3.92 \pm 0.22 \mathrm{mmol} / \mathrm{l}, \mathrm{p}=0.03$ respectively), where as HA1C level showed significant increases in the test group when compared with reference group (9.68 \pm 1.24 vs $5.44 \% \pm 0.42 \%, p=0.000$, and with significant elevation of both systolic and dystolic blood pressure $(\mathrm{p}=0.000)$.

As illustrated in Table 3, across gender there are no significant differences in serum $\mathrm{Na}^{+}$and $\mathrm{K}^{+}$levels in males when compared with females ( $\left.\mathrm{p}>0.05\right)$ in type 2 diabetic patients.

In Table 4, serum $\mathrm{Na}^{+}$level was significantly correlated with $\mathrm{K}^{+}(\mathrm{R}=0.369$, $\mathrm{p}=0.008)$. Whereas both serum $\mathrm{Na}^{+}$and $\mathrm{K}^{+}$were in significantly correlated with both patients age and $\mathrm{HbAlc}(\%)(\mathrm{p}>0.05)$ in the study group.

As shown in Figure 1 and Figure 2 both serum $\mathrm{K}^{+}$recorded insignificant correlation with duration of diabetes mellitus $(\mathrm{R}=0.248, \mathrm{p}=0.08$ and $\mathrm{R}=0.045$, $\mathrm{p}=0.758$ respectively) in the study group, Where as HA1C is significantly correlated with the duration of diabetes $(\mathrm{R}-=0.425, \mathrm{p}=0.002)$ in Figure 3.

\section{Discussion}

Type 2 diabetic individuals are at higher risks of Serious long-term complications associated with type 2 diabetes include cardiovascular disease, stroke, chronic kidney disease, foot ulcers, and damage to the eyes [12]. Electrolytes play an important role in several body mechanisms, and electrolyte imbalance is commonly present in patients with type 2 diabetes mellitus, the cause is usually multifactorial, but commonly results from insulin inactive or deficiency [5] [6] [12].

In the current study mean serum level of sodium and potassium were significantly decreased in type 2 diabetes patients Which are inconsistence with the studies performed by Nabil et al. 2016 [13] and Ugwuja et al. (2006) [14], and disagree with Sarguru et al. (2016) [15] and McDonnell et al. (2005) [16] Another studies conducted by Rashid et al. 2019 [17] and Alaka and Saurabh (2016) [18] observed that Serum $\mathrm{Na}^{+}$was significantly low and serum $\mathrm{Cl}^{-}, \mathrm{Ca}^{2+}$ 
Table 3. Mean comparison of study parameters in male versus female in the study group.

\begin{tabular}{cccc}
\hline Parameters & Male $($ Mean $\pm \mathrm{SD})$ & Female $($ Mean $\pm \mathrm{SD})$ & $P$-value \\
\hline $\mathrm{Na}^{+}(\mathrm{mmol} / \mathrm{L})$ & $137.0 \pm 3.39$ & $138.3 \pm 4.55$ & 0.258 \\
$\mathrm{~K}^{+}(\mathrm{mmol} / \mathrm{L})$ & $3.79 \pm 0.38$ & $3.99 \pm 0.40$ & 0.068 \\
$\mathrm{HbAlc}(\%)$ & $9.48 \pm 1.18$ & $9.87 \pm 1.29$ & 0.258 \\
$\mathrm{SPB}(\mathrm{mmHg})$ & $133.6 \pm 3.75$ & $132.4 \pm 3.68$ & 0.259 \\
$\mathrm{DBP}(\mathrm{mmHg})$ & $88.6 \pm 2.22$ & $88.76 \pm 2.57$ & 0.833 \\
\hline
\end{tabular}

Table 4. Correlation between $\mathrm{Na}^{+}, \mathrm{K}^{+}, \mathrm{HbAlc}(\%)$ and with patients age in the study group.

\begin{tabular}{ccccc}
\hline Variables & & $\mathrm{Na}^{+}(\mathrm{mmol} / \mathrm{L})$ & $\mathrm{K}^{+}(\mathrm{mmol} / \mathrm{L})$ & HbAlc $(\%)$ \\
\hline \multirow{2}{*}{ Age } & $\mathrm{R}$ & 0.241 & 0.10 & 0.378 \\
& $\mathrm{P}$ & 0.09 & 0.49 & 0.007 \\
Duration of DM & $\mathrm{R}$ & 0.248 & 0.045 & 0.425 \\
& $\mathrm{P}$ & 0.08 & 0.758 & 0.002 \\
$\mathrm{Na}^{+}(\mathrm{mmol} / \mathrm{L})$ & $\mathrm{R}$ & - & 0.369 & 0.175 \\
& $\mathrm{P}$ & - & 0.008 & 0.225 \\
$\mathrm{~K}^{+}(\mathrm{mmol} / \mathrm{L})$ & $\mathrm{R}$ & 0.369 & - & 0.061 \\
& $\mathrm{P}$ & 0.008 & - & 0.675 \\
$\mathrm{HbAlc}(\%)$ & $\mathrm{R}$ & 0.175 & 0.061 & \\
& $\mathrm{P}$ & 0.225 & 0.675 & \\
\hline
\end{tabular}

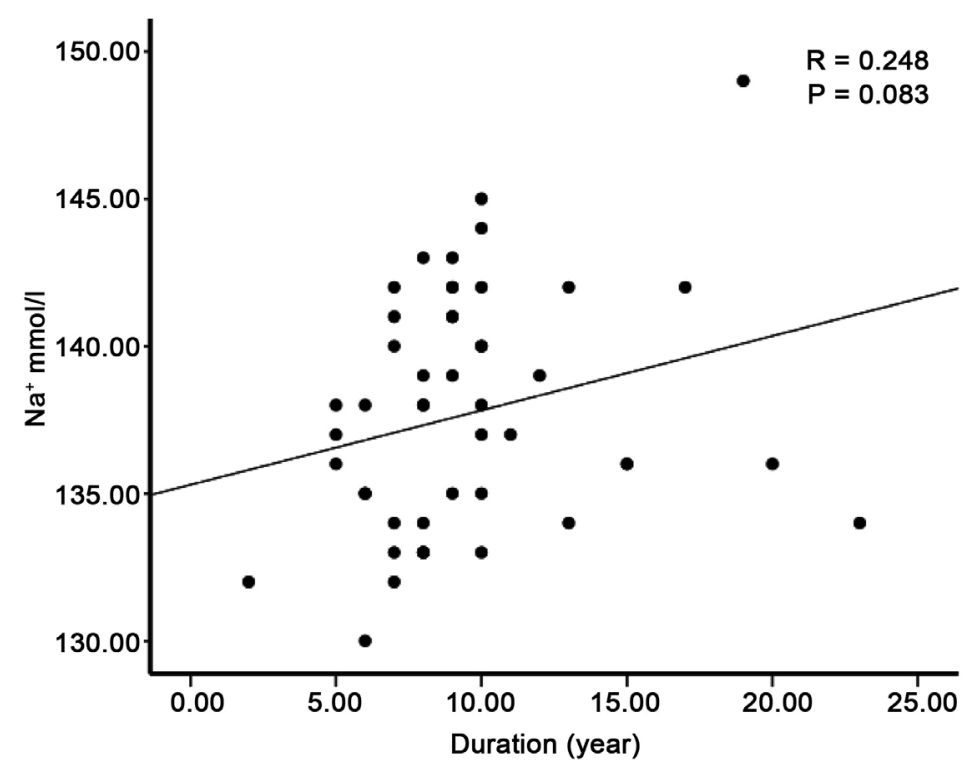

Figure 1. Correlation between serum sodium levels with duration of the diabetes mellitus in the study group.

were significantly increased in type $2 \mathrm{DM}$ compared to control. Insignificant high value of serum $\mathrm{K}^{+}$was observed in case compared to control. Wang et al. (2013) [19], reported only $0.6 \%$ of diabetes had hypokalemia and $1.2 \%$ of 


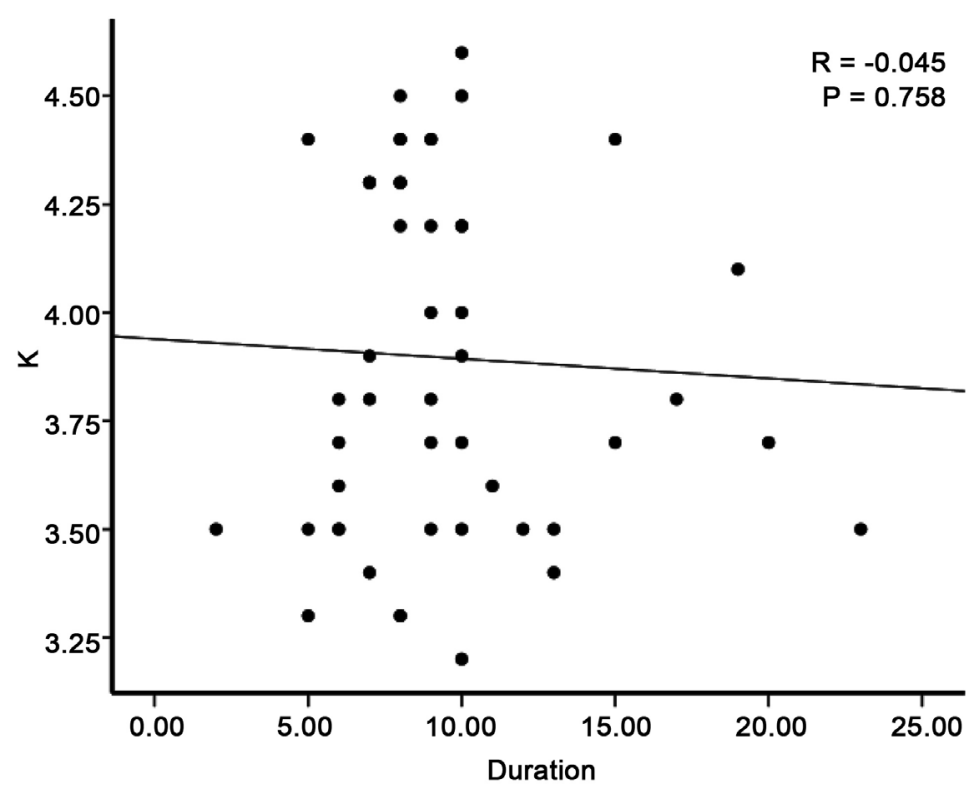

Figure 2. Correlation between serum potassium levels with duration of the diabetes mellitus in the study group.

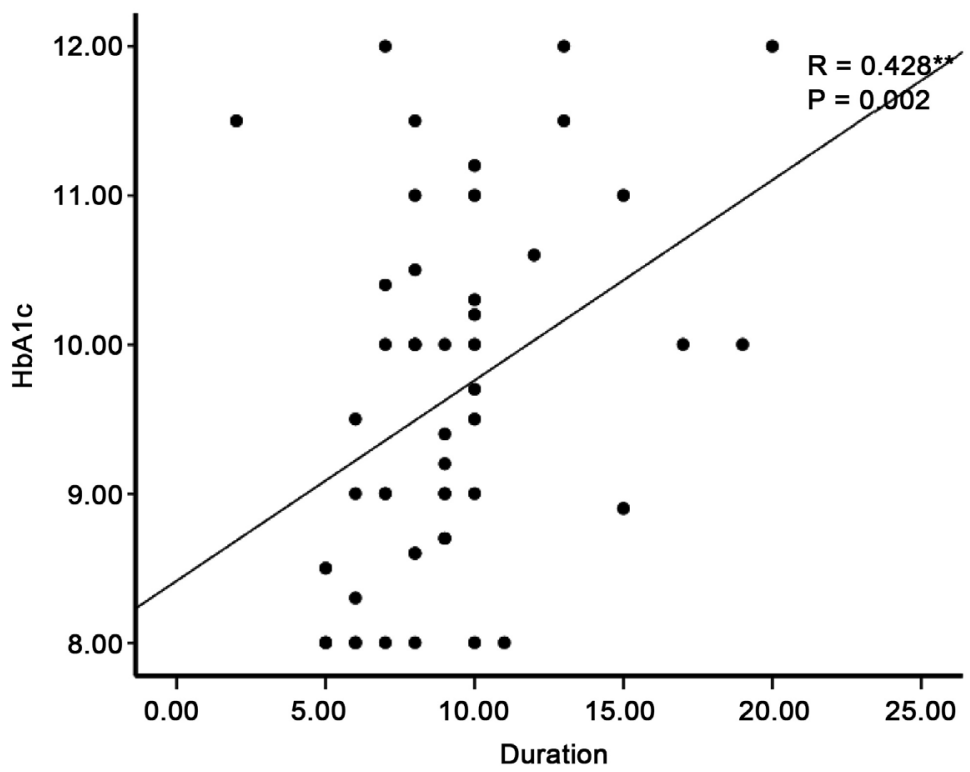

Figure 3. Correlation between $\mathrm{HbA} 1 \mathrm{c} \%$ levels with duration of the diabetes mellitus in the study group.

diabetes subjects had hyperkalemia. George et al. (2014) [20] perform an overview on electrolyte levels in type 2 diabetic patients, and observed that diabetic patients frequently develop a constellation of electrolyte disorders.

Across gender our study recorded insignificant alteration in serum $\mathrm{Na}$ and $\mathrm{K}$ levels ( $p>0.05)$ in type 2 diabetic patients.

The present study illustrated significant correlation between serum $\mathrm{Na}^{+}$and $\mathrm{K}^{+}$levels $(\mathrm{p}<0.05)$. Whereas both $\mathrm{Na}^{+}$and $\mathrm{K}^{+}$were in significantly correlated with patients age, HbAlc (\%), and duration of DM ( $p>0.05)$. 
Our study observed significant increases in $\mathrm{HA}_{1} \mathrm{C}$ level in the test group when compared with reference group, with significant correlation with the duration of diabetes $(\mathrm{P}=0.002)$. Elevated level of $\mathrm{HA}_{1} \mathrm{C}$ reflects uncontrolled $\mathrm{DM}$ which induced osmotic diuresis that may increase the urinary excretion of $\mathrm{Na}^{+}$and $\mathrm{K}^{+}$. It's proposed to be a primary mechanism responsible for the decreased serum concentrations of $\mathrm{Na}^{+}$and $\mathrm{K}^{+}$[20] [21].

\section{Conclusion}

Sodium and potassium imbalance is significantly present in patients with uncontrolled diabetes mellitus. Hence, electrolytes levels should be routinely determined in patients with type 2 diabetes mellitus.

\section{Acknowledgements}

We thank all the study participants, and we acknowledge the support of the staff of Asia hospital-Khartoum state, who provided the facilities for the interviews and the laboratory work.

\section{Conflicts of Interest}

The authors declare no conflicts of interest regarding the publication of this paper.

\section{References}

[1] Lobo, D.N. (2004) Fluid, Electrolytes and Nutrition: Physiological and Clinical Aspects. Proceedings of the Nutrition Society, 63, 453-466. https://doi.org/10.1079/PNS2004376

[2] Khubchandani, A.S. and Sanghani, H. (2013) Study of Serum Magnesium and HbA1C in Diabetic Patients along with Changes in Their Lipid Profiles. Indian Journal of Clinical Practice, 23, 717-719.

[3] Rao, G.M. (2002) Serum Electrolytes and Osmolality in Diabetes Mellitus. Indian Journal of Medical Sciences, 46, 301-303.

[4] Shahid, S.M., Rafique, R.O.O.M.A.N.A. and Mahboob, T.A.B.A.S.S.U.M. (2005) Electrolytes and Sodium Transport Mechanism in Diabetes Mellitus. Pakistan Journal of Pharmaceutical Sciences, 18, 6-10.

[5] Mohsin, R., Badar, B., Saeed, A. and Rehman, A. (2007) Type 2 Diabetes: The Relationship between the Serum Cholesterol and Triglycerides. The Professional Medical Journal, 14, 337-343.

[6] Harris, M.I., Flegal, K.M., Cowie, C.C., Eberhardt, M.S., Goldstein, D.E., Little, R.R. and Byrd-Holt, D.D. (1998) Prevalence of Diabetes, Impaired Fasting Glucose, and Impaired Glucose Tolerance in US Adults: The Third National Health and Nutrition Examination Survey, 1988-1994. Diabetes Care, 21, 518-524. https://doi.org/10.2337/diacare.21.4.518

[7] Barbagallo, M., Dominguez, L.J. and Resnick, L.M. (2007) Magnesium Metabolism in Hypertension and Type 2 Diabetes Mellitus. American Journal of Therapeutics, 14, 375-385. https://doi.org/10.1097/01.mjt.0000209676.91582.46

[8] Frei, U. and Schober-Halstenberg, H.J. (1999) Annual Report of the German Renal 
Registry 1998. QuaSi-Niere Task Group for Quality Assurance in Renal Replacement Therapy. Nephrology, Dialysis, Transplantation: Official Publication of the European Dialysis and Transplant Association European Renal Association, 14, 1085-1090. https://doi.org/10.1093/ndt/14.5.1085

[9] Liamis, G., Rodenburg, E.M., Hofman, A., Zietse, R., Stricker, B.H. and Hoorn, E.J. (2013) Electrolyte Disorders in Community Subjects: Prevalence and Risk Factors. The American Journal of Medicine, 126, 256-263. https://doi.org/10.1016/j.amjmed.2012.06.037

[10] Rohlfing, C.L., Little, R.R., Wiedmeyer, H.M., England, J.D., Madsen, R., Harris, M.I. and Goldstein, D.E. (2000) Use of GHb (HbAlc) in Screening for Undiagnosed Diabetes in the US Population. Diabetes Care, 23, 187-191.

"https://doi.org/10.2337/diacare.23.2.187

[11] Khaw, K.T., Wareham, N., Luben, R., Bingham, S., Oakes, S., Welch, A. and Day, N. (2001) Glycated Haemoglobin, Diabetes, and Mortality in Men in Norfolk Cohort of European Prospective Investigation of Cancer and Nutrition (EPICNorfolk). British Medical Journal, 322, 15. https://doi.org/10.1136/bmj.322.7277.15

[12] Kesaniemi, Y.A. and Grundy, S.M. (1983) Increased Low Density Lipoprotein Production Associated with Obesity. Arteriosclerosis: An Official Journal of the American Heart Association, 3, 170-177. https://doi.org/10.1161/01.ATV.3.2.170

[13] Hasona, N.A. and Elasbali, A. (2016) Evaluation of Electrolytes Imbalance and Dyslipidemia in Diabetic Patients. Medical Sciences, 4, 7. https://doi.org/10.3390/medsci4020007

[14] Ugwuja, E. and Eze, N. (2006) A Comparative Study of Serum Electrolytes, Total Protein, Calcium and Phosphate among Diabetic and HIV/AIDS Patients in Abakaliki, Southeastern, Nigeria. The Internet Journal of Laboratory Medicine, 2. https://doi.org/10.5580/15e5

[15] Datchinamoorthi, S., Vanaja, R. and Rajagopalan, B. (2016) Evaluation of Serum Electrolytes in Type II Diabetes Mellitus. International Journal of Pharmaceutical Sciences Review and Research, 40, 251-253.

[16] McDonnell, C.M., Pedreira, C.C., Vadamalayan, B., Cameron, F.J. and Werther, G.A. (2005) Diabetic Ketoacidosis, Hyperosmolarity and Hypernatremia: Are High-Carbohydrate Drinks Worsening Initial Presentation? Pediatric Diabetes, 6, 90-94. https://doi.org/10.1111/j.1399-543X.2005.00107.x

[17] Khan, R.N., Saba, F., Kausar, S.F. and Siddiqui, M.H. (2019) Pattern of Electrolyte Imbalance in Type 2 Diabetes Patients: Experience from a Tertiary Care Hospital. Pakistan Journal of Medical Sciences, 35, 797-801. https://doi.org/10.12669/pjms.35.3.844

[18] Das, A. and Borkotok, S. (2016) Evaluation of Serum Electrolyte Levels in Type 2 Diabetes Mellitus. Indian Journal of Applied Research, 6, Issue 8.

[19] Wang, S., Hou, X., Liu, Y., Lu, H., Wei, L., Bao, Y. and Jia, W. (2013) Serum Electrolyte Levels in Relation to Macrovascular Complications in Chinese Patients with Diabetes Mellitus. Cardiovascular Diabetology, 12, 146. https://doi.org/10.1186/1475-2840-12-146

[20] Liamis, G., Liberopoulos, E., Barkas, F. and Moses, E. (2014) Diabetes Mellitus and Electrolyte Disorders. World Journal of Clinical Cases, 2, 488-496. https://doi.org/10.12998/wjcc.v2.i10.488

[21] Pham, P.C., Pham, P.M., Pham, S.V., Miller, J.M. and Pham, P.T. (2007) Hypomagnesemia in Patients with Type 2 Diabetes. The Clinical Journal of the American Society of Nephrology, 2, 366-373. 
https://doi.org/10.2215/CJN.02960906

[22] Vallon, V., Richter, K., Blantz, R.C., Thomson, S. and Osswald, H. (1999) Glomerular Hyperfiltration in Experimental Diabetes Mellitus: Potential Role of Tubular Reabsorption. Journal of the American Society of Nephrology, 10, 2569-2576. 